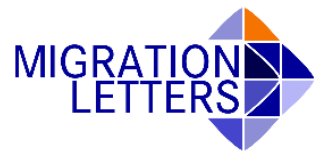

First Submitted: 29 April 2018 Accepted: 7 November 2018

DOI: https://doi.org/10.33182/ml.v16i1.628

\title{
It's the taking part that counts: Inequalities and simultaneous youth transnational engagement from six European countries
}

\author{
Laura Díaz-Chorne ${ }^{ \pm}$, Víctor Suárez-Lledó ${ }^{*}$ Javier Lorenzo ${ }^{\S}$
}

\begin{abstract}
In this article we investigate transnational engagement in the destination country and oriented towards the home country, offering a theoretical analysis of the often-neglected simultaneous nature of this phenomenon. Using two original indices, we empirically examine the extent to which young people from six countries (Germany, Hungary, Luxembourg, Norway, Romania and Spain) are involved in transnational political, economic, social and cultural activities. The study is based on two surveys carried out as part of the H2020 project MOVE, which studied youth mobility in Europe, with a sample of 8,706 young respondents (18-29 years old). Our findings show that migrants' transnational engagement in their home country and destination is not only simultaneous but mutually reinforcing. This engagement is affected by individual and institutional constraints, which shows that transnational ties and transactions not only produce inequalities but are affected by them.
\end{abstract}

Keywords: mobility; youth; transnational; simultaneity; inequality; Europe.

\section{Introduction}

The study of transnational migration sets the focus of research on the continuity of bonds between the origin country, destination country and others, and how it affects numerous social processes, most frequently migrants' social integration into their host societies (Levitt, 2001; Itzigsohn \& Saucedo, 2002; Morawska 2003, 2004; Fitzgerald, 2004; Snel et al., 2006; Portes et al., 2007), or the political (democratization) and economic development of their home countries (Orozco et al., 2005; Portes, 2007; Faist, 2008).

The literature on transnationalism refers to transformations in terms of mobility and daily interactions in contemporary societies, and has provided an alternative approach that has permitted the field to a) move away from push-pull and gravity models that remained anchored in nineteenthcentury concepts and assumptions (Massey et al., 1993) that were -still are sometimes- used to study migration routinely and uncritically (De Hass, 2011); b) move from the concept that migrants move from point A to point B to settle permanently, as a rational choice according to the relative attractiveness of both ends, towards a more dynamic concept of mobility (Sirkeci, 2009); and c) nuance previous assimilation theories, in which social and economic success depended on acculturation and assimilation into the host society, shifting towards the study of the maintenance

\footnotetext{
${ }^{ \pm}$Corresponding author: Laura Díaz-Chorne, Professional Spanish Association for Political Science and Sociology, Spain. E-mail: laura.diaz@colpolsoc.org.

¥ Victor Suárez-Lledó, Professional Spanish Association for Political Science and Sociology, Spain.

E-mail: victor.sanz@colpolsoc.org.

§avier Lorenzo, Universidad Carlos III de Madrid, Madrid, Spain. E-mail: javier.lorenzo@uc3m.es.

Acknowledgement: The research from the MOVE project has received funding from Horizon 2020 under Grant Agreement $\mathrm{N}^{\circ}$ 649263. The authors would like to thank the two anonymous reviewers and the editors of this issue for their very useful suggestions.
} 


\section{Inequalities and simultaneous youth transnational engagement}

of social networks across national borders while adapting instrumentally to a second cultural endowment (Portes et al., 1999; Snel et al., 2006).

Although the scope of this phenomenon has been contested by some scholars who argue that precursors of this present transnationality have always existed, or that the extent of the phenomenon has been exaggerated because it was built around qualitative studies that sampled on the dependent variable (Guarnizo et al., 2003), the general agreement is that the extension of transportation and communication technologies have meant a substantial difference to current mobility. Consequently, most scholars concur that at least some migrants are nowadays embedded in multi-sited, multilayered transnational social fields that equally affect those who move and those who stay behind (Levitt \&Glick-Schiller, 2004). While some argue that the importance of these information and communication technologies is more a case of facilitation than causation (Castells, 1996; Vertovec, 2001), it is certain that they have made it easier for migrants and even their non-mobile counterparts, despite physical absence, to re-establish a social presence and live their routine daily activities simultaneously in two societies (Portes et al., 1999; Mau, 2010; Boccagni, 2012).

Transnationality thus connects with the tensions between nomadism and "sedentarism", which has traditionally informed the social sciences and "treats as normal stability, meaning and place, and treats as abnormal distance, change and placelessness" (Sheller \& Urry, 2006: 208) and the increasing extension of mobility - understood as a general, more inclusive term that comprises migration (Cohen \& Sirkeci, 2011; Amelina \& Vasilache, 2014). One of its strengths is thus that it focuses more on the transnational ties and transactions that also affect short-term mobiles and even non-mobiles, rather than on the geographical movement itself (Dahinden, 2009; Mau, 2010; Faist, 2014; Amelina \& Vasilache, 2014; Herz, 2015). While it is important to set aside the short-sighted lens of methodological nationalism, it is just as important to note that sometimes nationalism seems to have been replaced by these other reified ideas of interconnectedness and constant movement, and to remember the continued potency of nation-states as a powerful institution and signifier (Wimmer \& Glick Schiller, 2002: 326).

Even though transnational studies in Europe -or about Europe- have been developed over recent decades with very relevant theoretical reflections (Pries, 2002; Bauböck, 2003; Favell, 2010, 2011; Faist, 2013, 2014; Chaudhary, 2016, 2017), there is less empirical research, and it commonly tends to focus on "third-country nationals" (Østergaard-Nielsen, 2001, 2003; Ehrkamp, 2005; Sirkeci \& Cohen, 2005, 2011, 2012, 2016; Morales \& Morariu, 2011; Lafleur, 2011; Boccagni, 2011; Morales \& Pilati, 2014). This article conversely sets the focus on the mobility of young Europeans (18-29 years old); those surveyed in the project move under a certain institutional protection in which mobility is facilitated, sometimes even promoted. That is not to say that the European Union is free from conflict and inequalities (Amelina \& Vasilache, 2014; Bilecen \& Van Mol, 2017), but our young respondents move in relatively accessible conditions from a legal point of view, which is reflected in easier access to the labour market, recognition of qualifications, etc.

Transnationality hence relates to inequalities in two ways. On the one hand the abovementioned institutional and individual constraints affect transnational engagement: less socially and economically favoured mobiles are more likely to be excluded from the receiving society and less likely to have the resources to maintain transborder connections and activities and even less to do so in a simultaneous way (Tsuda, 2012; Guarnizo et al., 2008; Itzigsohn \& Saucedo 2002; Portes, 2003). Engagement deals with this simultaneous participation in more than one nation-state and, as Tsuda (2012) points out, requires a certain degree of agency and active involvement, rather than embeddedness in the host society by mere physical presence. Thus, a previous interest in social, 
economic or political issues will improve individual engagement regardless of the place of residence, and that interest has a strong correlation with individual and institutional constraints (Putnam, 1995; Norris, 2000). Furthermore, transnationality, the extent to which young people partake in transnational ties and transactions, is not so much a resource in itself but rather a sign of heterogeneity or a marker of difference that often results in inequalities. The fact that transnationality is defined as a continuum, rather than a dichotomous trait that can be encountered even amongst the geographically immobile, somehow defies the idea that inequalities are still constructed nationally, and makes it a potentially more widespread sign of societal heterogeneity than mobility per se (Faist, 2014).

In the next pages we will primarily expand the theoretical argument that simultaneity is the main feature of transnationality, even though this attribute remains largely ignored in research, and we will propose an empirical attempt to measure such activities through the use of two indices. Later we will explore the effect of socio-demographic factors such as age, gender, education level, parents' educational level or mobility background of the family, and institutional contexts on transnational engagement.

\section{"Simultaneity is what transnationalism is about"? 1}

Although most definitions of transnationalism set the focus on its simultaneous nature (Portes et al., 1999: 217; Portes et al., 2002: 279; Levitt \& Glick-Schiller, 2004: 1003; Vertovec 2004: 9746; Levitt \& Jaworsky, 2007: 130; Mazzucato, 2010; Boccagni, 2012), simultaneity remains largely neglected in transnational studies; the field centres almost customarily on home-oriented activities (Levitt \& Schiller 2004; Tsuda, 2012).

We concur with Tsuda (2012: 10) on the fact that this simultaneous engagement in two societies is not only the key sociological feature of transnationalism, but also what constitutes the novelty of this approach that distinguishes it from long-distance nationalism or "transborderism". A perfect illustration of this is political transnationality, where the novelty cannot be conceived simply as an increase in activities oriented towards the home country; more importantly, it must be seen as the novel possibility of combining internal and external affiliations and statuses (Bauböck, 2003). Nowadays citizens exercise political rights, political parties run campaigns, and candidates combine political positions in two or more countries. A current example of this is the recent announcement by Manuel Valls, the former Prime Minister, Interior Minister and current Member of Parliament in France, that he is presenting his candidacy as the Mayor of Barcelona (Bassets, 2018), whereas a few decades ago citizenship and political loyalty to a single territory were considered indivisible (Faist, 2006).

A burgeoning number of studies consider how transnationality towards the home country is not incompatible with migrants' social integration (Snel et al., 2006; Fitzgerald, 2004; Itzigsohn \& Saucedo, 2002; Levitt, 2001; Levitt \& Glick Schiller, 2004; Morawska, 2003, 2004; Portes et al., 2007). However, very little research focuses on the dynamic and complementary relationship between mobiles' engagement in the home and host countries, and how their activities affect one other (Tsuda, 2012; Morawska, 2003).

Following Tsuda (2012), we developed the possible relationships between home and host country engagement and their simultaneity as follows:

a) A zero-sum situation in which engagement happens either in one place or the other. The prime example of this would be participation oriented towards the home country as a result of

${ }^{1}$ Tsuda, 2012: 3. 
barriers (closed political opportunity structures) preventing participation at the destination (Morales \& Pilati, 2014). Conversely, the more integrated the person becomes in the new society the less likely they are to participate in a manner oriented towards their home country, which is the basic premise of assimilation literature. The relationship between engagement in the host and home country is negative: participation in one place would mean a lack of participation in the other and vice versa. Simultaneity is also negative, as engagement does not happen simultaneously in both places.

b) Mutual negative reinforcement, where disengagement in one society causes disengagement in the other. The relationship between the two areas is positive: disengagement in one society would lead to disengagement in the other, and simultaneity remains negative, as it does not take place in both scenarios.

c) Co-existence, when engagement (or non-engagement) appears simultaneously in both the home and destination country with neither having a systematic influence on the other.

d) Mutual positive reinforcement, when home and host country engagement simultaneously encourages or enables increased engagement with the other. The relationship in this case is positive, as participation in one society enables engagement in the other and vice versa.

In contrast with the traditional assumption that engagement aimed towards one end will detract from the other, our main hypothesis is that we are under the fourth scenario (mutual positive reinforcement) and that activities in home and host country will reinforce the other.

Table 1 Simultaneous transnational behaviour matrix

\begin{tabular}{|c|c|c|c|c|}
\hline $\begin{array}{l}\text { Kind of } \\
\text { relationship }\end{array}$ & $\begin{array}{c}\text { Transnationality } \\
\text { oriented towards } \\
\text { home country }\end{array}$ & $\begin{array}{l}\text { Transnationality at } \\
\text { destination country }\end{array}$ & $\begin{array}{c}\text { Simultaneous } \\
\text { transnational } \\
\text { engagement }\end{array}$ & Relationship \\
\hline Zero-sum & $\begin{array}{l}+ \\
-\end{array}$ & $\begin{array}{l}- \\
+\end{array}$ & 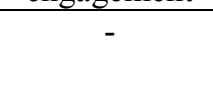 & - \\
\hline $\begin{array}{l}\text { Mutual negative } \\
\text { reinforcement }\end{array}$ & - & - & - & + \\
\hline Co-existence & + & + & + & none \\
\hline $\begin{array}{l}\text { Mutual positive } \\
\text { reinforcement }\end{array}$ & $\begin{array}{c}++ \\
+\end{array}$ & $\begin{array}{c}+ \\
++\end{array}$ & + & + \\
\hline
\end{tabular}

\section{Data and methods}

For our analyses, we use data generated in the EU project "MOVE: Mapping mobility pathways, institutions and structural effects of youth mobility in Europe" (Navarrete et al., 2017), which studied mobility in the EU in the fields of employment, higher education, vocational training, voluntary work, entrepreneurship and school exchanges.

The study of young migrants and mobiles faces the challenge of dealing with an "unknown or hidden population" (Heckathorn, 1997; Muhib et al., 2001; Platt et al., 2006). There is not only a low ratio of young people who move abroad, but also no census or official statistics on mobile people (Watters \& Biernacki, 1989). To address this difficulty we followed a dual strategy, examining young people (non-mobile and formerly mobile) through the use of an online panel service across the six consortium countries $(n=5,499)$, complemented by an online snowball survey 
to oversample the mobile population $(n=3,207) .{ }^{2}$ The field-work was conducted from November 2016 to January 2017. The respondents are young people aged between 18 and 29 from the six countries involved in the project selected, as they represent a range of diverse socio-economic, migratory and European membership contexts.

For the analyses in this article, we are using a merged weighted dataset that contains 8,706 respondents and our analysis focuses only on those with mobility experiences: 5,275 respondents (2,068 from the panel survey and 3,207 in the snowball survey). Mobility was practically defined as having been abroad for other reason than tourism and visiting relatives for more than two weeks. This soft concept was set to include all kinds of mobilities studied in the projects, such as vocational training or voluntary work, which are often short-term. The average length of stay in the sample is 8.7 months. Considering the nature of the population studied and the characteristics of the surveys, we use both surveys to obtain a larger sample, calibrate the bias, and balance the results with the goal of providing generalizable results. To that end, we merge the two samples and weight them using a post-stratification method. Post-stratification consists in estimating the calibration to reduce the variation of the estimates and the bias resulting from non-coverage and non-response (Kalton \& Flores-Cervantes, 2003). To apply this method, it is necessary to use auxiliary qualitative variables to configure the layers (Cobben \& Bethlehem, 2013). Once the layers are configured, the composition of each is compared with the official statistics (in our case EUROSTAT, 2015) for the variables of age, gender and education. Thus, more weight is given to respondents in underrepresented groups and less weight to over-represented groups. Once the process of stratification has been carried out, the resulting composition of the mobiles on the panel is used to calibrate the combined sample of mobiles in the panel and the snowball survey. Furthermore, in accordance with our commitment to carry out an analysis with a comparative approach, we calculate the weighting both at the aggregate level and at the country level. ${ }^{3}$

Table 2 Panel and snowball sample composition by country compared to Eurostat

\begin{tabular}{lrrrrrrrr}
\hline & \multicolumn{2}{c}{ Panel (Total) } & \multicolumn{2}{c}{ Panel (Mobiles) } & \multicolumn{2}{c}{ Snowball } & \multicolumn{2}{c}{ Eurostat } \\
\hline & Freq. & $\%$ & Freq. & \multicolumn{1}{c}{$\%$} & Freq. & \multicolumn{1}{c}{$\%$} & \multicolumn{1}{c}{ Freq. } & \multicolumn{1}{c}{$\%$} \\
\hline Germany & 961 & $17.5 \%$ & 367 & $17.7 \%$ & 1,124 & $35.0 \%$ & $11,720,972$ & $51.7 \%$ \\
\hline Hungary & 980 & $17.8 \%$ & 272 & $13.2 \%$ & 157 & $4.9 \%$ & $1,444,897$ & $6.4 \%$ \\
\hline Luxembourg & 739 & $13.4 \%$ & 438 & $21.2 \%$ & 231 & $7.2 \%$ & 90,824 & $0.4 \%$ \\
\hline Norway & 877 & $15.9 \%$ & 252 & $12.2 \%$ & 176 & $5.5 \%$ & 837,198 & $3.7 \%$ \\
\hline Romania & 976 & $17.7 \%$ & 322 & $15.6 \%$ & 354 & $11.0 \%$ & $2,862,824$ & $12.6 \%$ \\
\hline Spain & 966 & $17.6 \%$ & 417 & $20.2 \%$ & 1,165 & $36.3 \%$ & $5,708,794$ & $25.2 \%$ \\
\hline Total & 5,499 & $100 \%$ & 2,068 & $100 \%$ & 3,207 & $100 \%$ & $22,665,509$ & $100 \%$ \\
\hline
\end{tabular}

Table 3 Panel and snowball sample composition by age compared to Eurostat

\begin{tabular}{rrrrrrrrr}
\hline & \multicolumn{2}{l}{ Panel (Total) } & \multicolumn{2}{c}{ Panel (Mobiles) } & \multicolumn{2}{c}{ Snowball } & \multicolumn{2}{c}{ Eurostat } \\
\hline & Freq. & $\%$ & Freq. & $\%$ & Freq. & $\%$ & Freq. & $\%$ \\
\hline $18-24$ & 3,068 & $55.8 \%$ & 1,004 & $48.5 \%$ & 2,070 & $64.5 \%$ & $12,336,405$ & $54.4 \%$ \\
\hline $25-29$ & 2,431 & $44.2 \%$ & 1,064 & $51.5 \%$ & 1,137 & $35.5 \%$ & $10,329,104$ & $45.6 \%$ \\
\hline Total & 5,499 & $100 \%$ & 2,068 & $100 \%$ & 3,207 & $100 \%$ & $22,665,509$ & $100 \%$ \\
\hline
\end{tabular}

\footnotetext{
${ }^{2}$ Carried out by GfK with a proportional sample based on the gender and age-group distribution in the six consortium countries' populations.

${ }^{3}$ For further information see Appendix 1 and Navarrete et al., 2017.
} 
Table 4 Panel and snowball sample composition by sex compared to Eurostat

\begin{tabular}{lccrrrrrr}
\hline & \multicolumn{2}{c}{ Panel (Total) } & \multicolumn{2}{c}{ Panel (Mobiles) } & \multicolumn{2}{c}{ Snowball } & \multicolumn{2}{c}{ Eurostat } \\
\hline & Freq. & $\%$ & \multicolumn{1}{c}{ Freq. } & \multicolumn{1}{c}{$\%$} & Freq. & \multicolumn{1}{c}{$\%$} & \multicolumn{1}{c}{ Freq. } & $\%$ \\
\hline Male & 2,567 & $46.7 \%$ & 977 & $47.2 \%$ & 907 & $28.3 \%$ & $11,705,258$ & $51.6 \%$ \\
\hline Female & 2,932 & $53.3 \%$ & 1,091 & $52.8 \%$ & 2,300 & $71.7 \%$ & $10,960,251$ & $48.4 \%$ \\
\hline Total & 5,499 & $100 \%$ & 2,068 & $100 \%$ & 3,207 & $100 \%$ & $22,665,509$ & $100 \%$ \\
\hline
\end{tabular}

Table 5 Panel and snowball sample composition by level of education compared to Eurostat

\begin{tabular}{lcccccccc}
\hline & \multicolumn{2}{c}{ Panel (Total) } & \multicolumn{2}{c}{ Panel (Mobiles) } & \multicolumn{2}{c}{ Snowball } & \multicolumn{2}{c}{ Eurostat } \\
\hline & Freq. & $\%$ & Freq. & $\%$ & Freq. & $\%$ & Freq. & $\%$ \\
\hline $\begin{array}{l}\text { Post- } \\
\begin{array}{l}\text { secondary or } \\
\text { lower }\end{array}\end{array}$ & 3,138 & $57.1 \%$ & 922 & $44.6 \%$ & 1,429 & $44.6 \%$ & $18,328,582$ & $80.9 \%$ \\
\hline Tertiary & 2,361 & $42.9 \%$ & 1,146 & $55.4 \%$ & 1,778 & $55.4 \%$ & $4,337,471$ & $19.1 \%$ \\
\hline Total & 5,499 & $100 \%$ & 2,068 & $100 \%$ & 3,207 & $100 \%$ & $22,665,509$ & $100 \%$ \\
\hline
\end{tabular}

\section{Dependent variable: Transnational indices}

To perform our analysis, we used an analytical classification that is common throughout transnational literature and differentiates between transnational behaviours and attitudes (Boccagni, 2012), or what has been referred as ways of being and ways of belonging (Levitt \& Glick Schiller, 2004). In this article we focus on the ways of being or "actual social relations and practices in which individuals engage in their everyday lives" (Levitt \& Glick Schiller, 2004: 1010) rather than the dimension of identity. The difficult empirical operationalization of these activities (Mazzucato, 2008), the need to disaggregate them further (Boccagni, 2012; Faist, 2014) as we have attempted, and their uncertain hierarchy or reliability (Guarnizo, 2003; Waldinger, 2008; Boccagni, 2012) are common topics in the literature.

Dealing with simultaneity, the issue of how to integrate two different contexts into one analytical framework is one of the main methodological challenges raised when researching on transnationality (Levitt \& Schiller, 2004; Boccagni, 2012). Our way of coping with this was to include the same set of activities -social, economic, political, and cultural-in the questionnaire both at migrants' destinations and oriented towards their home societies. For the analysis, we developed two transnational indices (Díaz \& Suárez-Lledó, 2017) picking up on previous attempts in the literature (Mau et al., 2008; Faist et al., 2015; Bilecen \& Cardona, 2017) and considering transnationality as a continuum rather than a dichotomous trait (Faist, 2015); one is a transnational index of activities aimed towards the home country, the other mirror index refers to the transnational activities at the country of destination.

Each of these two indices ranges from 0 to 1 and comprises five sub-indices that represent $20 \%$ of the total value, following and widening common dimensions in transnational literature (Boccagni, 2012; Faist, 2014): political, cultural, social, informational, and economic activities, whose interval values also range from $0=$ non-existent participation in any of the proposed activities to 1 =participation in all activities. As Riedel (2017) points out, any chosen domains necessarily represent an arbitrary selection of transnational activities that somehow follow common distinctions in the literature. All the variables that compose these dimensions are measured in a dichotomous way: $0=$ no participation to $1=$ participation. To score high in the transnational index, the respondent must check several activities, rating diversity greater than regularity. The inclusion of variables in each domain followed a theoretical basis that was further tested in a polychoric factor analysis given 
the categorical nature of the chosen variables. There is a high correlation between the items of each of the factors and there is a certain correlation between each of the dimensions, although this correlation is never greater than the elements included in the dimensions. ${ }^{4}$ The factorial analysis created a four-dimensional index. However, with the aim of following a theoretical approach based on the literature, an economic dimension was created including those items, implying an economic transaction. To consider whether the variables should be included in the index, those with a greater frequency of response in relation to the country of origin were selected, given that most works on transnationality refer only to actions oriented towards the home country.

\section{Explanatory factors:}

A subset of explanatory factors identified as relevant in the literature in regards to transnationality were added in order to validate the indices' consistency. A set of socio-demographic traits were included as potential predictors for unequal levels of transnationality both at destination and towards the home country. Education and the education level of the mother are used as a proxy for socio-economic status, as described in the literature (Bukodi \& Goldthorpe, 2013; Erola et al., 2016). In the same vein, countries have been included in the models not as essentialist categories but as "categorical boundary-making" (Faist et al., 2015: 195) heterogeneous frameworks that structure young people's actions (Bilecen et al., 2017) and macro constraints reflecting the unequal conditions of departure among young people immersed in mobility experiences.

- Gender: Female/Male

- Level of education: Primary/Secondary/Tertiary

- Mother's level of education: Primary/Secondary/Tertiary

- Siblings studied abroad: Yes/No

- Length of stay in destination country: From less than a month to more than 5 years (0.84 to 72 months)

- Studying is main reason for mobility: Yes/No

- Financial independence: Dependent/Independent

- Money sent to home country: Sent money to people, invested or contributed to associations in your country while living abroad: Never, on a one-off occasion or regularly (1-3)

- Money sent to other country: Sent money to people, invested or contributed to associations in another country: Never, on a one-off occasion or regularly (1-3)

- Crisis: Financial or political situation in home country marked as important reason to move abroad: Yes/No

- Countries of origin: Germany, Spain, Hungary, Romania, Luxembourg, Norway.

In the next section, we present a series of OLS regressing the two dependent variables (transnationality index in home country and destination country) in three different scenarios:

1. The first seeks to validate the internal consistency of one of the sub-indices that conform the transnational index, regressing the five sub-indices to its contrary verifying the assumption simultaneity.

2. The second linear regression introduces explanatory factors (a set of variables regarding social, demographic and economic conditions at individual level) to understand whether they affect the outcome of our dependent variables equally or differently.

\footnotetext{
${ }^{4}$ See Appendix 2 for more information on the factorial analysis.
} 
3. The last regression shows the performance of those indices at country level, mainly accounting for the financial dependency of the respondents.

\section{Analysis and results}

Before the main findings are presented, let us recall the nature and scope of our research. Namely, the mobile population, even miscounted, remains a minority within the whole European population (3.9\% share of the total working-age population in the EU according to the 2017 Annual Report on intra-EU Labour Mobility), even less considering only the young population, aged 18 to 29. Moreover, as official statistics posit, the percentage of the population who decide to engage in political, cultural or economic activities is low not only amongst mobiles but also among the native population (OECD, 2016; Pew Research, 2016). This final section presents a first empirical attempt to provide an informed perspective on transnational activities among young people and whether or not they are performed both in the host country and oriented towards the home country.

In this section, we present results for the linear regression analyses to test the hypothesis for dimensions that affect the level of transnationality among young Europeans. Following our theoretical reasoning, first we regress the five sub-indices (social, political, economic, media and cultural) to the contrary index verifying the assumption of simultaneity. Secondly, a set of individual constraints reflecting different socio-demographic traits have been included as potential predictors for unequal levels of transnationality both at the destination and oriented towards the home country. Thirdly, countries are entered as macro constraints reflecting the unequal conditions of departure of young people immersed in mobility experiences, with Germany as the reference category.

Table 6 Transnational index by each one of the sub-indices

\begin{tabular}{lclc}
\hline Dependent Variable & $\begin{array}{c}\text { Model 1 } \\
\text { Dest. Country } \\
\text { Index }\end{array}$ & & $\begin{array}{c}\text { Model 2 } \\
\text { Home Country } \\
\text { Index }\end{array}$ \\
\hline (Intercept) & $0.226^{* * *}$ & (Intercept) & $0.236^{* * *}$ \\
& $(0.006)$ & $0.006)$ \\
\hline Index social & $0.083^{* * *}$ & $\begin{array}{l}\text { Index social } \\
\text { dest. country }\end{array}$ & $0.067^{* * *}$ \\
home country & $(0.008)$ & Index cultural & $(0.011)$ \\
\hline Index cultural & $0.034^{* * *}$ & dest. country & $0.031^{* * *}$ \\
home country & $(0.008)$ & Index media & $(0.009)$ \\
\hline Index media & $0.084^{* * *}$ & dest. country & $0.081^{* * *}$ \\
home country & $(0.007)$ & Index political & $(0.007)$ \\
\hline Index political & $0.131^{* * *}$ & dest. country & $0.058^{* * *}$ \\
home country & $(0.014)$ & Index economic & 0.014 \\
\hline Index economic & 0.015 & dest. country & $0.139^{* * *}$ \\
home country & $(0.013)$ & & $(0.013)$ \\
\hline Observations & 5275 & & 5275 \\
\hline Residual & 0.161 & & 0.176 \\
Std. Error & & & 0.112 \\
\hline $\boldsymbol{R}^{\mathbf{2}}$ & 0.118 & & 0.111 \\
\hline Adjusted $\boldsymbol{R}^{2}$ & 0.117 & & \\
\hline
\end{tabular}




\section{Simultaneous relationship}

The first model validates the internal consistency of our measuring tool, confirming the significant relationships between the sub-indices from one to the reverse general index. More interestingly, it confirms the hypothesis that greater engagement in the destination country implies greater engagement in the home country and vice versa. Therefore, we can infer that a mutual positive reinforcement in transnational activity exists, consistent with the previous literature, which posits that those individuals who tend to engage, tend to do it more and everywhere (Chaudhary, 2016).

Each one of the sub-indices' coefficients has a similar influence on each dependent variable, which shows the consistency of the transnational index and its dimensions. The economic sub-index does not have any effect on the destination country, while being one of the most explanatory factors for the home country index. On the contrary, for a one-point increase in the political sub-index, the destination country index increases by 1.3 ceteris paribus, while the increase for the home country index is less than .05 points.

\section{Individual constraints}

In terms of the consistency of the model, the first result to highlight is the difference in the explanatory factor between the home country index (.044) and the destination country index (.149), meaning that the importance of sociodemographic traits with regard to transnational engagement is better explained at the destination country.

Individual traits associated with inequalities, such as the respondent's level of education, have a positive impact on transnationality in both the destination and home country, being greater in the former than the latter. Results confirm that there are greater participation ratios among those with a higher education level, with a significant relationship for both indices stronger at the destination. The mother's education level only affects transnationality significantly at the destination, not in the home country. Accordingly, the effect of having a background of mobility in the family has a positive effect on the transnationality index in the destination country.

Table 7 Transnationality and individual constraints

\begin{tabular}{lcc}
\hline Dependent Variable & $\begin{array}{c}\text { Model 1 } \\
\text { Destination Country Index }\end{array}$ & $\begin{array}{c}\text { Model 2 } \\
\text { Home Country Index }\end{array}$ \\
\hline (Intercept) & $0.290^{* * *}(0.012)$ & $0.335^{* * *}(0.014)$ \\
\hline Gender (reference: Female) & $0.002(0.005)$ & $-0.008(0.006)$ \\
\hline Level of edu. (ref: Secondary) & $0.058^{* * *}(0.010)$ & $0.025^{*}(0.012)$ \\
\hline Level of edu. (ref: Tertiary) & $0.076^{* * *}(0.011)$ & $0.039^{* *}(0.013)$ \\
\hline Mother's level of edu. (ref: Secondary) & $0.016^{* *}(0.006)$ & $0.001(0.007)$ \\
\hline Mother's level of edu. (ref: Tertiary) & $0.024^{* * *}(0.006)$ & $0.001(0.008)$ \\
\hline Siblings studied abroad (ref: No) & $-0.015^{* *}(0.006)$ & $-0.001(0.007)$ \\
\hline Length of stay & $0.042^{* * *}(0.003)$ & $0.033^{* * *}(0.003)$ \\
\hline Type of mobility (ref: Studies) & $0.024^{* * *}(0.005)$ & $0.021(0.006)$ \\
\hline Finan. independent (ref: Independent) & $-0.012^{*}(0.006)$ & $0.007(0.006)$ \\
\hline Sent money home country (ref: Yes) & $0.019^{* * *}(0.003)$ & $0.010^{* *}(0.003)$ \\
\hline Sent money oth. country (ref: Yes) & $0.013^{* * *}(0.003)$ & $-0.002(0.003)$ \\
\hline Observations & 3878 & 3878 \\
\hline Residual Std. Error & 0.151 & 0.179 \\
\hline $\boldsymbol{R}^{2}$ & 0.151 & 0.047 \\
\hline Adjusted $\boldsymbol{R}^{\mathbf{2}}$ & 0.149 & 0.044 \\
\hline
\end{tabular}




\section{Inequalities and simultaneous youth transnational engagement}

In regards to the length of stay, the longer the stay abroad is, the more youth engagement in transnational activities there is. In this case, the relationship is significant and positive for both indices. Those young respondents who decided to move abroad for academic reasons tend to engage in most of the dimensions more frequently than those who moved for employment or other reasons. Youth engagement scores in both indices positively and with similar intensity, although it shows a significant relationship only in the destination country. Being financially independent has a (small) negative significant relationship only towards the destination country, while sending money to the home country has a significant positive effect on both indices.

\section{Country Level}

It is worth noting that although the coefficients remain significant but low, the difference in the explanatory factor between the home country index (.11) and the destination country index (.058) acts in the opposite direction than for individual constraints, meaning that the importance of the country of origin regarding transnational engagement is better explained by participation aimed towards the home country.

All countries but Romania present a significant positive effect for transnational engagement aimed towards the home country. Young people form Luxembourg and Spain tend to engage more in the destination and home countries than their contemporaries from the other countries in the sample. Being from Romania and Hungary has a significant negative effect on transnationality in the destination country. Those respondents who signalled that their financial or political situation was an important reason to move abroad engage significantly less in the destination country.

Table 8 OLS Transnationality at country level

\begin{tabular}{lcc}
\hline Dependent Variable & $\begin{array}{c}\text { Model 1 } \\
\text { Destination Country Index }\end{array}$ & $\begin{array}{c}\text { Model 2 } \\
\text { Home Country Index }\end{array}$ \\
\hline (Intercept) (ref: Germany) & $0.369^{* * *}(0.004)$ & $0.308^{* * *}(0.005)$ \\
\hline Crisis (ref: Yes) & $-0.018^{* *}(0.007)$ & $-0.011(0.007)$ \\
\hline Hungary & $-0.079^{* * *}(0.009)$ & $0.046^{* * *}(0.009)$ \\
\hline Luxembourg & $0.045^{* * *}(0.008)$ & $0.131^{* * *}(0.009)$ \\
\hline Norway & $-0.018(0.010)$ & $0.073^{* * *}(0.010)$ \\
\hline Romania & $-0.059^{* * *}(0.008)$ & $-0.001(0.009)$ \\
\hline Spain & $0.026^{* * *}(0.006)$ & $0.137^{* * *}(0.007)$ \\
\hline Observations & 4616 & 4616 \\
\hline Residual Std. Error & 0.161 & 0.172 \\
\hline $\boldsymbol{R}^{2}$ & 0.058 & 0.11 \\
\hline Adjusted $\boldsymbol{R}^{\mathbf{2}}$ & 0.057 & 0.109 \\
\hline
\end{tabular}

\section{Conclusions and discussion}

The main outcome of our analysis supports the hypothesis that transnational engagement takes place in a simultaneous fashion, and that greater engagement in the destination country also implies greater engagement aimed towards the home country and vice versa, rather than what was posited by previous assimilation theories. Furthermore, we can say that the nature of this simultaneity in our sample is that of mutual positive reinforcement, in which acts of home and host country engagement encourage or enable one other (Tsuda, 2012). Each one of the sub-indices' coefficients has a similar influence on each dependent variable, although for the destination country the index of economic activities does not have any effect, while it is one of the most explanatory factors for transnational engagement aimed towards the home country. By contrast, the political sub-index is 
one of the most explanatory indices for the destination country, while it remains irrelevant for the home country.

The analyses also confirm the impact of unequal individual and institutional constraints on transnational engagement both in the destination country and towards the home country. The socially and economically favoured are more likely to participate in the host society and more likely to have the resources to maintain transborder connections and activities, as portrayed in the literature (Portes, 2003; Tsuda, 2012). As Chaudhary (2017) posits, the nature of the relationship between integration and transnational engagement may ultimately be complementary among motivated immigrants with the resources and abilities to engage in activities "here" and "there". Hence, young people who participate in any of the areas under consideration in the receiving country do so in all the others: this transnational engagement could ultimately be an indicator of good integration in general, while engagement in some activities implies a greater ease of access to participation in others.

Greater socio-economic status has a positive impact on engagement in both the destination and home countries, the impact being greater in the former than the latter, as was to be expected. Interestingly, the education level of the mother, a proven trigger for mobility (Navarrete et al., 2017), only affects engagement significantly in the destination country, and does not significantly affect engagement aimed towards the home country, which shows that socioeconomic status (parental education, and financial independence) is more relevant to engagement in activities in the destination country. Likewise, young respondents who move abroad primarily for academic reasons tend to engage in most of the dimensions more frequently than those who move primarily for employment, showing a significant relationship at the destination, corroborating the assumption that those who have more resources and time tend to participate more in the host country. The length of stay also positively affects transnational engagement in both the host and home countries. These results reflect however the nature of our sample, in which the average length of stay is 8.7 months. It is an interesting result in itself, as short-term mobilities are understudied; yet, further research is needed on how this engagement decreases or rises in the long term.

Countries of origin - included in the models as heterogeneous frameworks that structure young people's actions (Bilecen et al., 2017) or macro constraints reflecting the unequal conditions of departure - act in the opposite direction to individual constraints, meaning that the importance of the country of origin with regard to transnational engagement is better explained in terms of participation aimed towards the home country. The diversity of dimensions means that the explanatory variables and the country-level effects cancel one other out. That is, a significant relationship in a destination country might be affected by a greater level of political participation or a higher interaction rate with the social network of relatives and friends. These results confirm previous research indicating that not only the context of destination (political opportunity structures at destination) but also the context of origin matter for transnational engagement (Morales \& Pilati, 2014). Of the countries included in our sample, respondents from Spain and Luxembourg tend to engage more, both at their destination and, especially, in acts oriented towards the home country. A possible explanation for this behaviour is not only that the socially and economically favoured are more likely to maintain transborder connections and activities, as stated above, but also that social networks and strong attachment to families and local communities represent an important impact (Van Dalen \& Henkens, 2012; Cairns, 2014; Navarrete et al., 2017). Respondents from Romania and Hungary, on the other hand, are linked to a significant negative effect on transnationality in the host country, accompanied by a positive significant effect on transnationality aimed towards the 


\section{Inequalities and simultaneous youth transnational engagement}

home country among Hungarians and no significant effect among Romanians, which could be taken as an indicator of more difficult integration into the host society.

Our results confirm that transnational activity remains socioeconomically embedded, and that individual and institutional context matter. Not only do inequalities affect transnational participation, but transnationality constitutes a societal heterogeneity or marker of difference that often results in further inequalities which are potentially more wide-reaching than mobility itself (Faist, 2014). Empirical research on the effect of transnational connections and activities on those who are not mobile will add to this knowledge. Given the exploratory character of this research, further research with exogenous data using the transnational index would be interesting. Furthermore, in order to strengthen the generalizability of the transnational index, a review of the activities and dimensions considered and a long-term analysis with other countries included in this project could benefit the outcome.

\section{References}

Amelina, A. and Vasilache, A. (2014). "The shadows of enlargement: Theorising mobility and inequality in a changing Europe”, Migration Letters, 11(2): 109-124. https://doi.org/10.33182/ml.v11i2.233

Baubock, R. (2003). "Toward a Political Theory of Migrant Transnationalism", International Migration Review, 37: 700-723.

Bilecen, B. and Cardona, A. (2018). "Do transnational brokers always win? A multilevel analysis of social support", Social Networks, 53: 90-100.

Bilecen, B. and Van Mol, C. (2017). "Introduction: international academic mobility and inequalities", Journal of Ethnic and Migration Studies, 43(8): 1241-1255.

Bassets, M. (23 ${ }^{\text {rd }}$ September 2018). "El salto de Valls a Barcelona intriga y desconcierta en Francia", El País. Retrieved from https://elpais.com/politica/2018/09/22/actualidad/1537639924_835342.html

Boccagni, P. (2011). "Migrants' social protection as a transnational process: public policies and emigrant initiative in the case of Ecuador", International Journal of Social Welfare. 20, (3) : 318-325

Boccagni, P. (2012). "Chapter 14: Even a transnational social field must have its boundaries. Methodological options, potential and dilemmas for researching transnationalism", Handbook of Research Methods in Migration: 295-318.

Bukodi, E. and Goldthorpe, J. H. (2012). 'Decomposing 'social origins': The effects of parents' class, status, and education on the educational attainment of their children", European Sociological Review, 29(5): 1024-1039.

Castells, M. (1996). The Rise of the Network Society. The Information Age: Economy, Society, and Culture Volume I (Information Age Series). London: Blackwell.

Chaudary, A. R. (2017). "Voting here and there: political integration and transnational political engagement among immigrants in Europe", Global Networks.

Chaudhary, A. R. (2016). “Transnational politics and immigrant political participation in Europe”, Working Paper, International Migration Institute, University of Oxford, 127: 1-22. http://www. imi. ox. ac. uk/publications/transnational-politics-and-political-integration-amongmigrants-in-europe. Accessed March 27.

Cobben, F. and Bethlehem, J. (2013). Web panels for official statistics. The Hague, The Netherlands: Statistics Netherlands.

Cohen, J. H. and Sirkeci, I. (2011). Cultures of migration: The global nature of contemporary mobility. Austin: University of Texas Press.

Cohen, J. and Sirkeci, I. (2005). A comparative study of Turkish and Mexican transnational migration outcomes. In: Henke, H. (ed.) Crossing over: comparing recent migration in the United States and Europe. Oxford: Lexington Books: 147-63. 
Dahinden, J. (2009). "Are we all transnationals now? Network transnationalism and transnational subjectivity: the differing impacts of globalization on the inhabitants of a small Swiss city", Ethnic and Racial Studies, 32(8): 1365-1386.

Díaz-Chorne, L. and Suarez-Lledo, V. (2017). The bonds to remain committed to the home country. In: Navarrete et al., (2017). MOVE D.4.7, 2017 Part of the MOVE-project: Mapping mobility - pathways, institutions and structural effects of youth mobility.

Ehrkamp, P. (2005). "Placing identities: Transnational practices and local attachments of Turkish immigrants in Germany", Journal of Ethnic and Migration studies, 31(2): 345-364.

Erola, J., Jalonen, S. and Lehti, H. (2016). "Parental education, class and income over early life course and children's achievement", Research in Social Stratification and Mobility, 44: 33-43.

EUROSTAT, Educational attainment and transition from education to work (based on EU-Labour Force Survey), Young people by education, sex and age 2015. Retrieved from http://appsso.eurostat.ec.europa.eu/nui/show.do?dataset=yth_demo_040\&lang=en

Faist, T. (2006). "The Transnational Social Spaces of Migration”, Working Papers. Center on Migration, Citizenship and Development, (10): 3-8.

Faist, T. (2008). "Migrants as transnational development agents: an inquiry into the newest round of the migration-development nexus", Population, space and place, 14(1): 21-42.

Faist, T. (2013). "The mobility turn: a new paradigm for the social sciences?", Ethnic and Racial Studies, 36(11): 1637-1646.

Faist, T. (2014). "We are all transnationals now: the relevance of transnationality for understanding social inequalities". In The History of Migration in Europe (pp. 89-107). Routledge.

Faist, T. and Bilecen, B. (2015). "Social inequalities through the lens of social protection: notes on the transnational social question", Population, Space and Place, 21(3): 282-293.

Favell, A. (2010). "Integration Policy and integration research in Europe". In: Aleinikoff, T. A., and Klusmeyer, D. (Eds.) Citizenship today: global perspectives and practices. Brookings Institution Press.

Favell, A. (2011). Eurostars and Eurocities: Free movement and mobility in an integrating Europe (Vol. 56). John Wiley \& Sons.

Fitzgerald, D. (2004). "Beyond 'transnationalism': Mexican hometown politics at an American labour union", Ethnic and Racial Studies, 27(2): 228-247.

Fries-TerschE, Tugran, T., Rossi, L. and Bradley, H.. (2018). 2017 Annual Report on intra-EU Labour Mobility. European Commission Directorate-General for Employment, Social Affairs and Inclusion, Publications Office of the European Union, Luxembourg

Guarnizo, L. (2008). Londres latina: la presencia colombiana en la capital británica. Miguel Angel Porrua.

Guarnizo, L. E. (2003). "The Economics of Transnational Living”, International Migration Review, 37 (3)

Guarnizo, L. E., Portes, A. and Haller, W. (2003). "Assimilation and transnationalism: determinants of transnational political action among contemporary migrants", American journal of Sociology, 108(6): 1211-1248.

Heckathorn, D. D. (1997). "Respondent-driven sampling: a new approach to the study of hidden populations", Social problems, 44(2): 174-199.

Herz, A. (2015). "Relational constitution of social support in migrants' transnational personal communities". Social Networks, 40(1): 64-74.

Itzigsohn, J. and Saucedo, S. G. (2002). "Immigrant incorporation and sociocultural transnationalism", International migration review, 36(3): 766-798.

Kalton, G. and Flores-Cervantes, I. (2003). "Weighting methods". Journal of Official Statistics, 19(2): 81.

Lafleur, J. M. (2011). "The transnational political participation of Latin American and Caribbean migrants residing in Europe", International Migration, 49(3): 1-9.

Levitt, P. (2001). “Transnational migration: taking stock and future directions", Global networks, 1(3): 195216. 


\section{Inequalities and simultaneous youth transnational engagement}

Levitt, P. and Jaworsky, B. N. (2007). Transnational Migration Studies: Past Developments and Future Trends Introduction: The Emergence of a Transnational Optic. https://doi.org/10.1146/annurev. soc. 33.040406 .131816

Levitt, P. and Glick Schiller, N. (2004). "Conceptualizing simultaneity: A transnational social field perspective on society", International migration review, 38(3): 1002-1039.

Massey, D. S., Arango, J., Hugo, G., Kouaouci, A., Pellegrino, A., and Taylor, J. E. (1993). "Theories of international migration: A review and appraisal", Population and development review: 431-466.

Mau, S. (2010). Social transnationalism: Lifeworlds beyond the nation-state. Routledge.

Mau, S., Mewes, J. \& Zimmermann, A. (2008). Cosmopolitan attitudes through transnational social practices? Global Networks, 8(1):1-24.

Mazzucato, V. (2010). "Operationalising transnational migrant networks through a simultaneous matched sample methodology”. In: Bauböck, R., Faist, T. (Eds.), Diaspora and Transnationalism: Concepts, Theories and Methods. Amsterdam University Press: 205-226.

Morales, L. and Morariu, M. (2011). Is 'Home'a distraction? The role of migrants' transnational practices in their political integration into receiving-country politics. In Social Capital, Political Participation and Migration in Europe: 140-171. Palgrave Macmillan, London.

Morales, L. and Pilati, K. (2014). "The political transnationalism of Ecuadorians in Barcelona, Madrid and Milan: the role of individual resources, organizational engagement and the political context", Global Networks, 14(1): 80-102.

Morawska, E. (2003). "Immigrant transnationalism and assimilation: a variety of combinations and the analytic strategy it suggests". In: C. Joppke and E. Morawska (eds) Toward assimilation and citizenship: immigrants in liberal nation-states. Basingstoke/New York: Palgrave Macmillan: 133-76.

Morawska, E. (2004). "Exploring diversity in immigrant assimilation and transnationalism: Poles and Russian Jews in Philadelphia", International Migration Review, 38(4): 1372-1412.

Muhib, F. B., Lin, L. S., Stueve, A., Miller, R. L., Ford, W. L., Johnson, W. D., ... \& Community Intervention Trial for Youth Study Team. (2016). A venue-based method for sampling hard-to-reach populations. Public health reports.

Navarrete et al. (2017) MOVE D.4.7, 2017 Part of the MOVE-project: Mapping mobility - pathways, institutions and structural effects of youth mobility.

Norris, P. (2000). A virtuous circle: Political communications in postindustrial societies. New York: Cambridge University Press.

OECD. (2016). Better Life Index, Civic Engagement. Retrieved from http://www.oecdbetterlifeindex. org/topics/civic-engagement/

Orozco, M., Lowell, L., Bump, M. and Fedewa, R. (2005). "Transnational engagement, remittances and their relationship to development in Latin America and the Caribbean" Institute for the Study of International Migration, Georgetown.

Østergaard-Nielsen, E. (2003). Transnational politics: The case of Turks and Kurds in Germany. Routledge.

Østergaard-Nielsen, E. K. (2001). "Transnational political practices and the receiving state: Turks and Kurds in Germany and the Netherlands", Global Networks, 1(3): 261-282.

Pew Research Center. (2016). "Even in Era of Disillusionment, Many Around the World Say Ordinary Citizens Can Influence Government” Retrieved from: http://www.pewglobal.org/2016/10/24/even-inera-of-disillusionment-many-around-the-world-say-ordinary-citizens-can-influence-government/civicparticipation-02/

Platt, L., Wall, M., Rhodes, T., Judd, A., Hickman, M., Johnston, L. G., ... and Sarang, A. (2006). "Methods to recruit hard-to-reach groups: comparing two chain referral sampling methods of recruiting injecting drug users across nine studies in Russia and Estonia". Journal of Urban Health, 83(1): 39-53.

Portes, A. (2003). "Conclusion: Theoretical convergencies and empirical evidence in the study of immigrant transnationalism”, International migration review, 37(3), 874-892.

Portes, A., Escobar, C. and Radford, A. W. (2007). "Immigrant transnational organizations and development: A comparative study", International migration review, 41(1): 242-281. 
Portes, A., Guarnizo, L. E. and Haller, W. J. (2002). "Transnational entrepreneurs: An alternative form of immigrant economic adaptation", American sociological review: 278-298.

Portes, A., Guarnizo, L. E. and Landolt, P. (1999). "The study of transnationalism: pitfalls and promise of an emergent research field”, Ethnic and Racial Studies, 22(2): 217-237.

Pries, L. (2002). "La migración transnacional y la perforación de los contenedores de Estadosnación", Estudios demográficos y urbanos: 571-597.

Putnam, R. (1995). "Bowling alone: America's declining social capital”, Journal of Democracy,: 65-78.

Riedel, S. (2017). "The problems of assessing transnational mobility: Identifying latent groups of immigrants in Germany using factor mixture analysis", Social Indicators Research, 131(1): 271-290.

Sheller, M., and Urry, J. (2006). “The New Mobilities Paradigm”. Environment and Planning A 38 (2): 208.

Sirkeci, I. (2009). "Transnational mobility and conflict", Migration Letters, 6(1):3-14. DOI: https://doi.org/10.33182/ml.v6i1.82

Sirkeci, I. and Cohen, J. H. (2016). "Cultures of migration and conflict in contemporary human mobility in Turkey”, European Review, 24(3): 381-396.

Sirkeci, I., Cohen, J. H. \& Yazgan, P. (2012). "Turkish culture of migration: Flows between Turkey and Germany, socio-economic development and conflict", Migration Letters, 9(1): $33 . \quad$ DOI: https://doi.org/10.33182/ml.v9i1.201

Snel, E., Engbersen, G. and Leerkes, A. (2006). "Transnational involvement and social integration", Global networks, 6(3), 285-308.

Tsuda, T. (2012). "Whatever Happened to Simultaneity? Transnational Migration Theory and Dual Engagement in Sending and Receiving Countries", Journal of Ethnic and Migration Studies

Vertovec, S. (2001). “Transnationalism and identity”, Journal of Ethnic and Migration studies, 27(4): 573 582.

Vertovec, S. (2004). "Migrant transnationalism and modes of transformation. International Migration Review, 38(3): 970-1001.

Waldinger, R. (2008). "Between "here" and "there": immigrant cross-border activities and loyalties", International Migration Review 42(1).

Watters, J. K. and Biernacki, P. (1989). "Targeted sampling: options for the study of hidden populations", Social problems, 36(4): 416-430

Wimmer, A. and Glick-Schiller, N. (2002). "Methodological nationalism and beyond: nation-state building, migration and the social sciences", Global Networks 2: 301-334. 


\section{Appendix}

1. Weighting and post-stratification

For the sake of brevity, here we include the formula developed for weighting by poststratification following Cobben and Bethlehem (2013)

$$
w_{k 2}=\frac{n_{p m, h} / n_{p m}}{\left(n_{p m, h}+n_{s, h}\right) /\left(n_{p m}+n_{s}\right)}
$$

where $n_{\mathrm{p}}$ and $n_{\mathrm{s}}$ represent the whole sample from the panel and snowball survey, respectively, and $n_{\mathrm{p}}=n_{\mathrm{pnm}}+n_{\mathrm{pm}}$ where $n_{\mathrm{pm}}$ is the number of mobile and $n_{\mathrm{pnm}}$ non-mobile respondents. Thus the mobiles from both samples were combined as one $\left(\mathrm{sm}=n_{\mathrm{pm}} \mathrm{U} / n_{\mathrm{s}}\right)$ with $n_{\mathrm{m}}=\mathrm{n}_{\mathrm{pm}}+n_{\mathrm{s}}$. Applying a second poststratification process leads to a list with the first 20 strata with the highest correction factor:

$\begin{array}{lllllll} & & \text { COUNTRY } & \text { AGE } & \text { GENDER } & \text { EDUCATION } & \text { wf3 } \\ 1 & 5221 & \text { Romania } & 25-29 & \text { Female } & \text { Secondary or less } & 7.46 \\ 2 & 6211 & \text { Spain } & 25-29 & \text { Male } & \text { Tertiary } & 6.15 \\ 3 & 1211 & \text { Germany } & 25-29 & \text { Male } & \text { Tertiary } & 5.47 \\ 4 & 5211 & \text { Romania } & 25-29 & \text { Male } & \text { Tertiary } & 5.24 \\ 5 & 6221 & \text { Spain } & 25-29 & \text { Female } & \text { Secondary or less } & 4.00 \\ 6 & 1111 & \text { Germany } & 18-24 & \text { Male } & \text { Tertiary } & 3.73 \\ 7 & 1221 & \text { Germany } & 25-29 & \text { Female } & \text { Secondary or less } & 2.87 \\ 8 & 1212 & \text { Germany } & 25-29 & \text { Male } & \text { Tertiary } & 2.29 \\ 9 & 6111 & \text { Spain } & 18-24 & \text { Male } & \text { Tertiary } & 1.82 \\ 10 & 5111 & \text { Romania } & 18-24 & \text { Male } & \text { Tertiary } & 1.48 \\ 11 & 2211 & \text { Hungary } & 25-29 & \text { Male } & \text { Tertiary } & 1.41 \\ 12 & 1121 & \text { Germany } & 18-24 & \text { Female } & \text { Secondary or less } & 1.19 \\ 13 & 1222 & \text { Germany } & 25-29 & \text { Female } & \text { Secondary or less } & 1.19 \\ 14 & 2221 & \text { Hungary } & 25-29 & \text { Female } & \text { Secondary or less } & 1.06 \\ 15 & 5121 & \text { Romania } & 18-24 & \text { Female } & \text { Tertiary } & 0.99 \\ 16 & 2111 & \text { Hungary } & 18-24 & \text { Male } & \text { Secondary or less } & 0.95 \\ 17 & 4211 & \text { Norway } & 25-29 & \text { Male } & \text { Secondary or less } & 0.78 \\ 18 & 6212 & \text { Spain } & 25-29 & \text { Male } & \text { Secondary or less } & 0.78 \\ 19 & 1112 & \text { Germany } & 18-24 & \text { Male } & \text { Tertiary } & 0.69 \\ 20 & 6121 & \text { Spain } & 18-24 & \text { Female } & \text { Secondary or less } & 0.67\end{array}$


2. Path diagrams representation of polychoric factor analysis: ${ }^{5}$

Factor analysis - home country

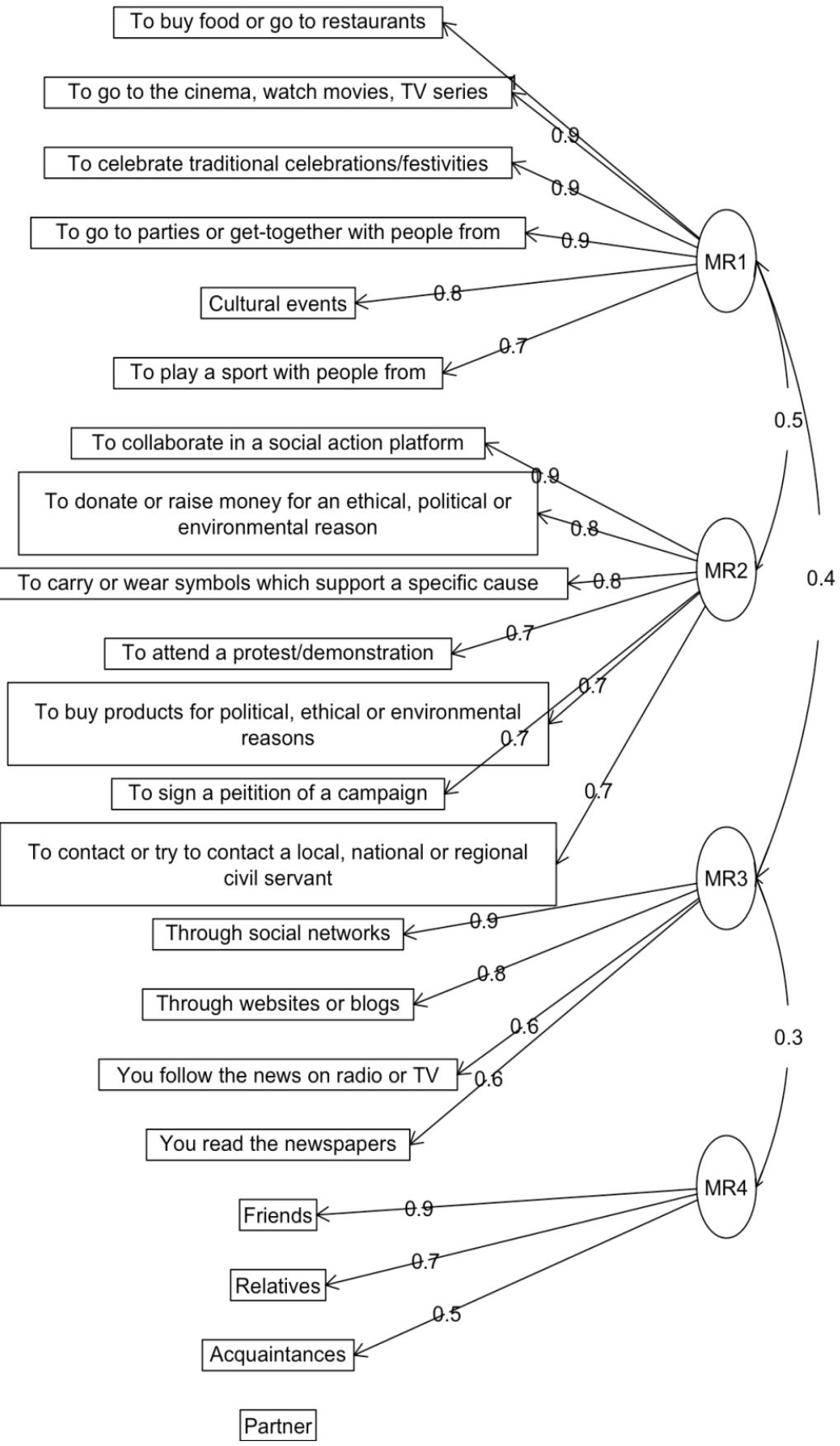

${ }^{5}$ Cultural items are grouped in MR1, political items in MR2, informational items in MR3 and social items in MR4. To simplify the path diagrams for factor analysis, only correlations up to 0.3 are shown. 


\section{Factor analysis - destination country}

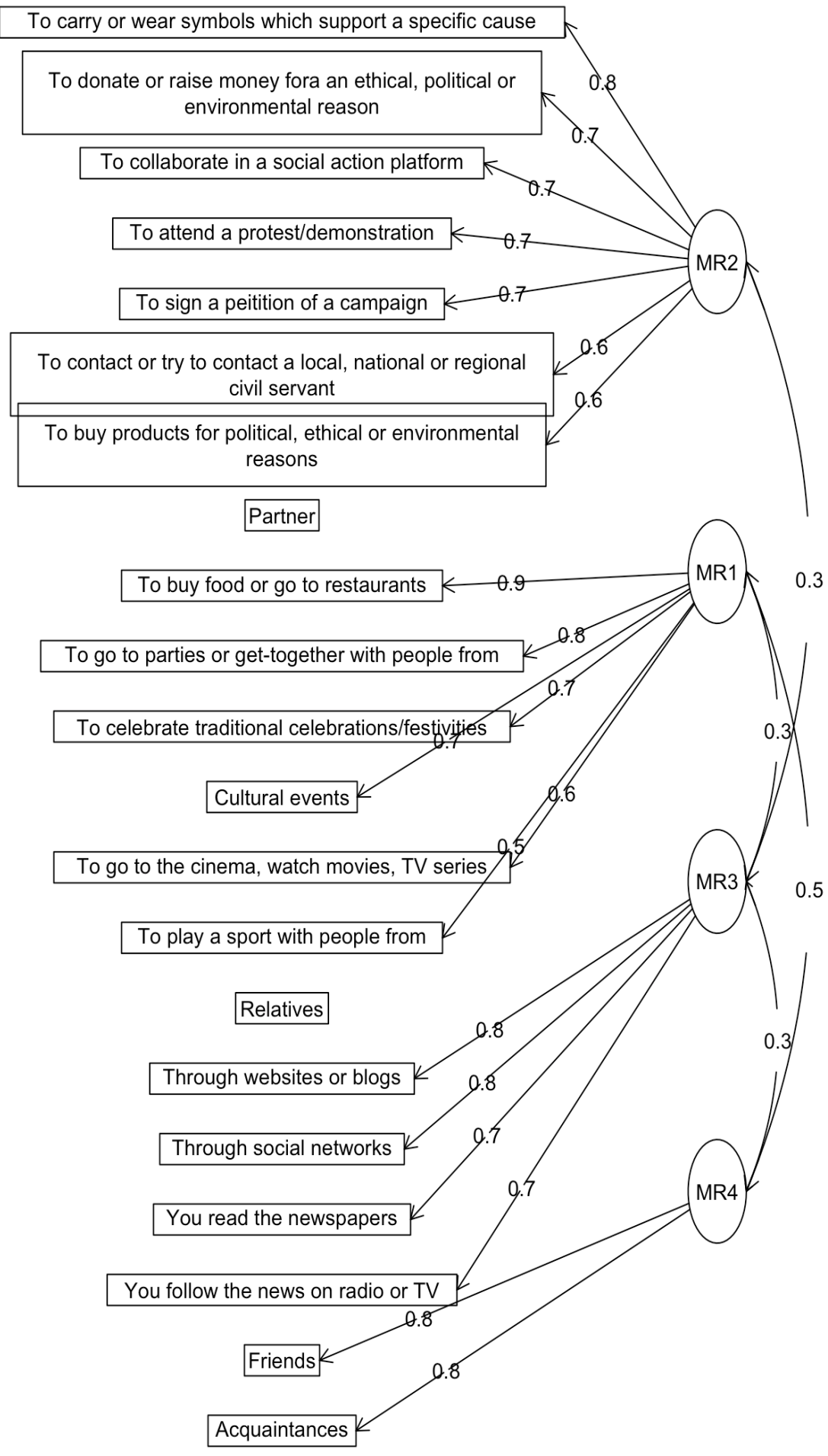




\begin{tabular}{|c|c|c|c|}
\hline Dimensions & Question & Items & Note \\
\hline $\begin{array}{l}\text { Economic } \\
\text { dimension }\end{array}$ & $\begin{array}{l}\text { "During your stay in } \\
\text { (country) in (year) did you } \\
\text { ever take part in any of the } \\
\text { activities mentioned } \\
\text { below?" }\end{array}$ & $\begin{array}{l}\text { - Buy food or go to restaurants from. . } \\
\text { - Buy products for political, ethical or } \\
\text { environmental reasons } \\
\text { - Donate or raise money for ethical, } \\
\text { political or environmental reasons }\end{array}$ & $\begin{array}{l}\text { The economic dimension } \\
\text { considers various aspects } \\
\text { related both to political } \\
\text { and cultural activities }{ }^{6} \text { : }\end{array}$ \\
\hline $\begin{array}{l}\text { Social } \\
\text { dimension }\end{array}$ & $\begin{array}{l}\text { "While you were in } \\
\text { (country) in (year), who } \\
\text { did you stay in touch with } \\
\text { at least once a week?" }\end{array}$ & $\begin{array}{l}\text {-Stay in touch at least once a week with } \\
\text { Partner } \\
\text {-Stay in touch at least once a week with } \\
\text { Relatives } \\
\text {-Stay in touch at least once a week with } \\
\text { Friends } \\
\text {-Stay in touch at least once a week with } \\
\text { Acquaintances }\end{array}$ & $\begin{array}{l}\text { For the social dimension, } \\
\text { we used the question at } \\
\text { the destination and in the } \\
\text { home country. }\end{array}$ \\
\hline $\begin{array}{l}\text { Informational } \\
\text { dimension }\end{array}$ & $\begin{array}{l}\text { "During your stay in } \\
\text { (country) in (year), did you } \\
\text { stay informed of events } \\
\text { happening in your country } \\
\text { and host country?" }\end{array}$ & $\begin{array}{l}\text {-You follow the news on radio or TV } \\
\text {-You read the newspapers printed or } \\
\text { digital } \\
\text {-Through websites or blogs } \\
\text { - Through social networks (Twitter, } \\
\text { Facebook, Linkedin, etc.) }\end{array}$ & $\begin{array}{l}\text { The informational } \\
\text { dimension takes into } \\
\text { account those } \\
\text { informative sources used } \\
\text { by mobile young people } \\
\text { to keep informed about } \\
\text { events in their country of } \\
\text { origin and in their } \\
\text { country of mobility. }\end{array}$ \\
\hline $\begin{array}{l}\text { Political } \\
\text { dimension }\end{array}$ & $\begin{array}{l}\text { "During your stay in } \\
\text { (country) in (year), did you } \\
\text { ever take part in any of the } \\
\text { activities mentioned } \\
\text { below?" }\end{array}$ & $\begin{array}{l}\text { - Sign a petition of a campaign } \\
\text { - Attend a protest/demonstration } \\
\text { - Contact or try to contact a local, } \\
\text { national or regional civil servant } \\
\text { - Collaborate in a social-action } \\
\text { platform } \\
\text { - Carry or wear symbols which support } \\
\text { a specific cause }\end{array}$ & $\begin{array}{l}\text { The political dimension } \\
\text { includes those activities } \\
\text { related to various aspects } \\
\text { of political participation } \\
\text { both toward home and } \\
\text { host countries: }\end{array}$ \\
\hline $\begin{array}{l}\text { Cultural } \\
\text { dimension }\end{array}$ & $\begin{array}{l}\text { "Did you take part in any } \\
\text { of the following } \\
\text { cultural/recreational } \\
\text { activities during your stay } \\
\text { in (country) in (year)?" }\end{array}$ & $\begin{array}{l}\text { - Cultural events: go to museums, } \\
\text { galleries, exhibitions, theatre, dance, } \\
\text { opera of.. } \\
\text { - Go to the cinema, watch movies, TV } \\
\text { series from. . . } \\
\text { - Celebrate traditional } \\
\text { celebrations/festivities of. . . } \\
\text { - Play a sport with people from. . } \\
\text { - Go to parties or get together with } \\
\text { people from. . . }\end{array}$ & $\begin{array}{l}\text { The cultural dimension, } \\
\text { based on the Special } \\
\text { Eurobarometer } 399 \\
\text { (2013) includes different } \\
\text { aspects related to various } \\
\text { cultural activities (of and } \\
\text { with people from the } \\
\text { home and host countries) }\end{array}$ \\
\hline
\end{tabular}

${ }^{6}$ Send money to the home country and other countries was left out but has been used as an explanatory variable. 
92 Inequalities and simultaneous youth transnational engagement

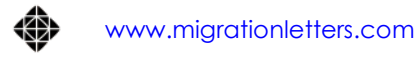

